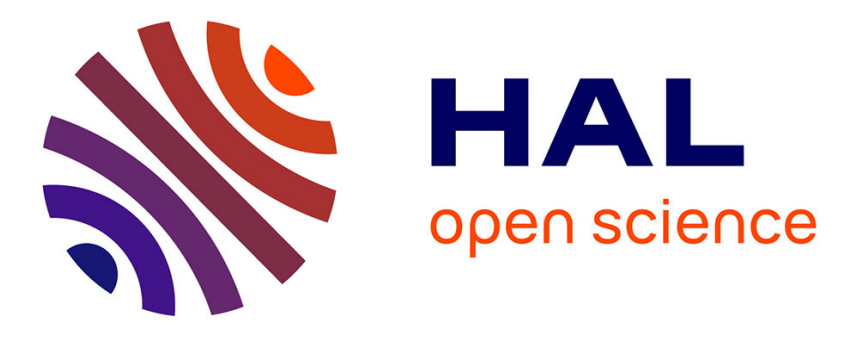

\title{
Experience of a Lifetime: Erasmus+ Traineeship Mobility on a Wind Energy Project
}

Benoit Barbe, Segundo Esteban, Mathilde Santos, Christophe Pasquier

\section{To cite this version:}

Benoit Barbe, Segundo Esteban, Mathilde Santos, Christophe Pasquier. Experience of a Lifetime: Erasmus+ Traineeship Mobility on a Wind Energy Project. 14th International Conference on Computational Intelligence in Security for Information Systems and 12th International Conference on European Transnational Educational (CISIS 2021 and ICEUTE 2021). CISIS - ICEUTE 2021, 2021, 978-3-030-87871-9. 10.1007/978-3-030-87872-6_34. hal-03474837

\section{HAL Id: hal-03474837 \\ https://hal.uca.fr/hal-03474837}

Submitted on 16 Dec 2021

HAL is a multi-disciplinary open access archive for the deposit and dissemination of scientific research documents, whether they are published or not. The documents may come from teaching and research institutions in France or abroad, or from public or private research centers.
L'archive ouverte pluridisciplinaire HAL, est destinée au dépôt et à la diffusion de documents scientifiques de niveau recherche, publiés ou non, émanant des établissements d'enseignement et de recherche français ou étrangers, des laboratoires publics ou privés.

\section{(c)(1)}

Distributed under a Creative Commons Attribution| 4.0 International License 


\title{
Experience of a Lifetime: Erasmus+ Traineeship Mobility on a Wind Energy Project
}

\author{
Benoit Barbe ${ }^{1(\otimes)}$, Segundo Esteban ${ }^{2}{\text {, Matilde } \text { Santos }^{3} \text { (D) , and Christophe Pasquier }}^{4}$ \\ ${ }^{1}$ Polytech Clermont, 63100 Aubière, France \\ benoit.barbedetu.uca.fr \\ 2 Faculty of Physics, University Complutense of Madrid, 28040 Madrid, Spain \\ sesteban@ucm.es \\ ${ }^{3}$ Institute of Knowledge Technology, University Complutense of Madrid, 28040 Madrid, Spain \\ msantos@ucm.es \\ 4 Electrical Engineering Department, Polytech Clermont, 63100 Aubière, France \\ christophe.pasquier@uca.fr
}

\begin{abstract}
International mobility enriches both, educational institutions and students that enjoy it. In this paper, the process of getting an Erasmus+ traineeship and the benefits derived from it are presented. This work shares the experience of a group of French students who have enjoyed an internship at a Spanish university in 2021. The importance of preparing the stay and the procedure to be carried out from both educational institutions, the one of origin and the receiving, is shown. For the successful of this mobility, it is also key to define a project that motivates the students and suits their background and skills. In this case, a project focused on renewable energies has been proposed. It consists on the design of a floating wind turbine prototype. Clean energy has proven to be very attractive to students and it is a way to discover new vocations for young researchers.
\end{abstract}

Keywords: Internationalization · Transnational · University · Education · Erasmus $\cdot$ Renewable energies $\cdot$ Wind energy project

\section{Introduction}

The internationalization of a university has been always seen as something beneficial for the institution [1]. But there are actions that promote this internationalization that have a direct impact on the students, and therefore benefit and enrich both, the education institution and the applicants [2]. This is the case of the mobility actions that are carried out among students from European universities under different agreements. This transnational aspect, so important in university education, has been stopped by the COVID' 19 pandemic in many places [3, 4]. However, in some countries this possibility has remained open.

A growing literature addresses the experiences of international students in higher education [5]. This work shares the experience of a group of French students who have enjoyed a Erasmus+ traineeship at a Spanish university in 2021. Specifically, a group of

(C) The Author(s), under exclusive license to Springer Nature Switzerland AG 2022

J. J. Gude Prego et al. (Eds.): CISIS 2021/ICEUTE 2021, AISC 1400, pp. 1-10, 2022.

https://doi.org/10.1007/978-3-030-87872-6_34 
students from the Polytech Clermont have spent a four-month stay (from May to August) at the Complutense University of Madrid, in order to collaborate on a research project.

The framework of this mobility is the Erasmus+ traineeship program of the European Union. ERASMUS is the acronym of the name of the programme: European Community Action Scheme for the Mobility of University Students. The purpose of the ERASMUS Programme is to further student mobility within Europe [6]. The Erasmus+ traineeship program is offered for students currently enrolled in higher education institutions in Programme countries at Bachelor and Master level as well as for doctoral candidates. These opportunities are also open to recent graduates. This specific program aims at not only to improve communication, language and inter-cultural skills, but also soft skills highly valued by future employers [7].

Throughout this paper, the importance of preparing the stay and the procedure to be carried out from both educational institutions, the one of origin and the host, is shown. For the successful of the exchange, it is also key to define the project in which the students are going to work on, and this project should suit their background and skills. In this case, the project aimed to be a motivational one. It is focused on renewable energies, something the attracts the students and connects with their ideals of a cleaner world. It is aligned with one of the main topics that the 2021-2027 Erasmus programme is fostering, the green and digital transitions [7]. Specifically, the design of a floating wind turbine prototype is proposed.

The structure of the paper is as follows. Section 2 describes the procedure to apply for the Erasmus grant from the student point of view, and the advantages and difficulties they may face. Section 3 presents the policy of the destination university. In Sect. 4 the project and the tasks assigned to the student are explained. The paper ends with the conclusions and future works.

\section{The University of Origin}

International mobility is a commitment by the Network Charter's Polytech. It can take the form of a study visit or a work placement. The destinations concern all the countries of the world. The Polytech schools have a dense network of international relations which enables them to offer various possibilities.

The Polytech network actively participates in European programs dedicated to education and especially the Erasmus+ program. "Meeting the challenges of tomorrow", motto of the Polytech network, means for some students to get out of their knowledge field, out of their home country, their habits, their comfort, to eventually find a new vision of how technology and innovation can improve the way we live.

The policy of the Polytech school in Clermont (Fig. 1) drives students to do an internship abroad during the degree, for a minimum of three months. The conditions are the same as for an internship in France. The Polytech advises the students to enjoy this mobility before the last year of the degree, so they may gain international experience while studying. This way they can also check one's ability to adapt before joining a larger mobility program or getting a job abroad [8].

Engineering students are encouraged to personally approach potential host companies or universities. Just in case of difficulty, they will turn to the relevant departments at Polytech Clermont (International Relations Department) and/or to the University (UCA). 


\section{POLYTECH CLERMONT}

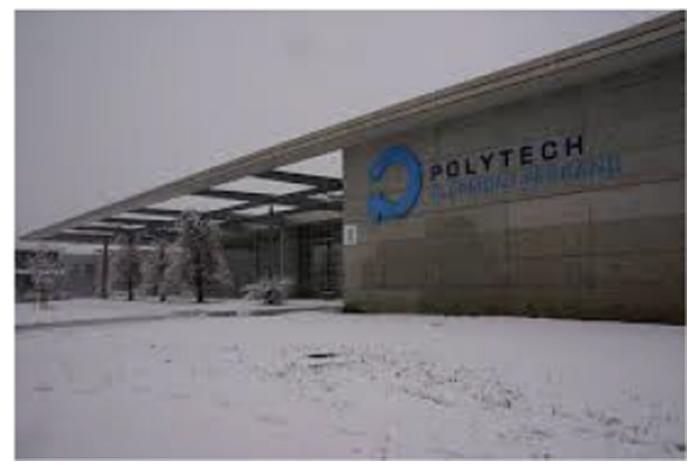

Fig. 1. Polytech Clermont (France).

\subsection{A Personal Experience: A Long Process to Get There}

As the first co-author of this paper, I will share my experience.

This internship was, first of all, an opportunity to confront myself with the difficulties of working on an international project in a foreign country. Of course, it was also a way to improve my English and the official language of the destination, in this case, Spanish. But what most matters, working with a foreign team collaborating in a real research project was really exciting. This definitely enriches the curriculum and, more important, our preparation for the professional life.

The student, the own higher education institution and the receiving organisation must sign a Learning Agreement for Traineeships to ensure a transparent and efficient preparation of the exchange abroad. This document sets out rights and responsibilities of the various parties, a detailed programme of the traineeship, information on insurance, and how your traineeship will be recognised upon successful completion.

The procedure to get all the paperwork done depends on the different ways each University and country has to solve the bureaucracy.

In our case, we, the students of Engineering, have to make the first move. That is, we must contact the host company or university and to define the topic of the internship. Then, it must be validated by the corresponding Department. Internships abroad have to be justified and the work done presented on our return to France, to be evaluated.

This financial support is available to all students. However, it is essential to pay attention to the selection criteria. The grant application files are received by the International Relations Office in Nice. In this case, I was able to open an Erasmus+ application which would allow me to obtain the funding if I proved a certain level of English knowledge and submitted the completed documentation on time (Fig. 2).

In a second step, I went to the Auvergne-Rhône-Alpes region in which I study, where I was able to obtain financial aid on the condition that I submit a complete file on my return from my internship on the different activities I have carried out. And finally, I went to the city of Chamalières, where I live, to find out if I was eligible for an international mobility grant. The essential criterion was that I had to justify my schooling for the year 2020/2021 and to hand in a completed file on my return to France, as for the financial aid from the Auvergne-Rhône-Alpes region. 
The last phase of this long process is to contact a suitable destination university. You have to choose among all the universities that have an Erasmus agreement with the Polytech School. University Complutense of Madrid (Spain) was a possible option. Even more, you must contact someone at the Complutense University that is willing to receive students and who can offer a project for the internship.
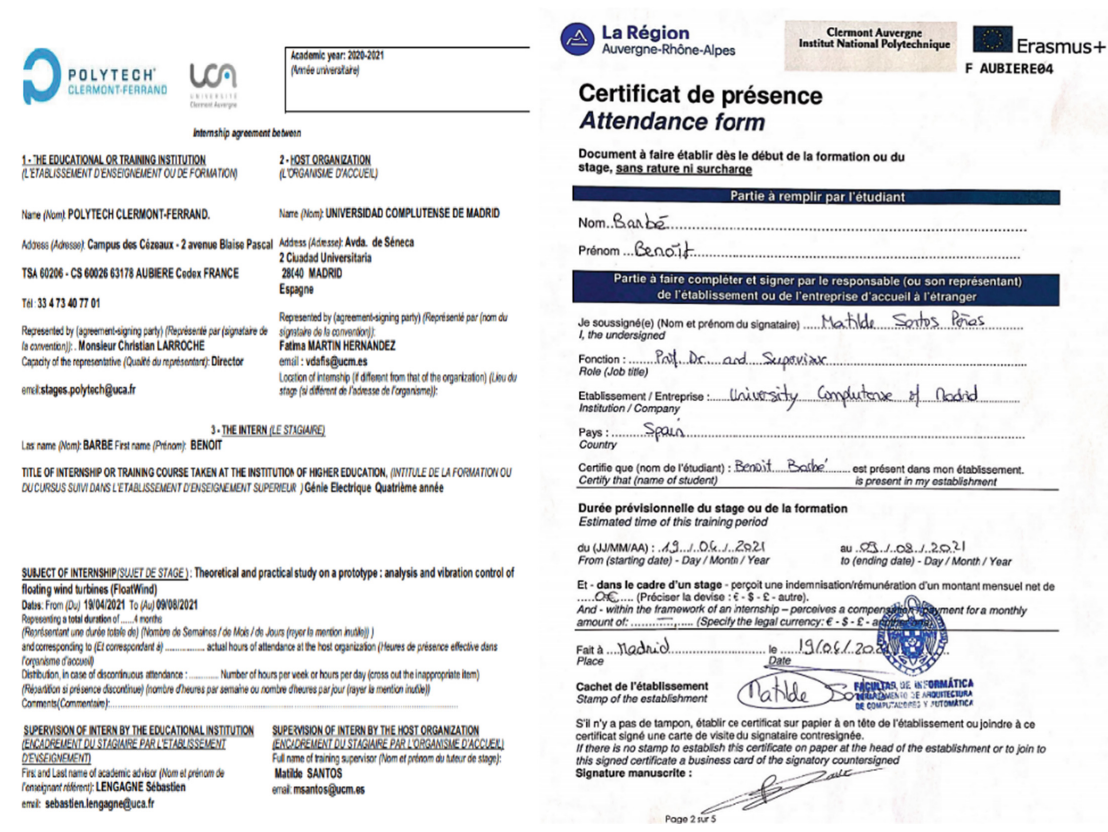

Fig. 2. Internship agreement (left) and Erasmus agreements (right).

In my case, I was offered a project that I found very interesting. It was focused on renewable energies. It was the design of a prototype of a wind turbine and its control. I decided to take it as it sounded very attractive. I though my background would allow me to work on it, particularly if I address it form the electronic point of view. I hoped to fulfill the expectations, though the topic was quite difficult and complex. But this opportunity was an ideal starting point to promote what I believe in: to contribute to develop new and clean ways to generate electricity.

\subsection{Pros and Cons}

Once I have decided to go abroad with this Erasmus+ traineeship, I reflected on the pros and cons.

- As a student of a technical degree, working in Madrid will allow me to experience the innovation cycle from the inside, to join technical meetups, and stay up to date with the new developments in a current and innovative field. 
- In addition, to learn new ways of working, different techniques, and to develop some skills and learn new concepts in a foreign country can pave the way for fundamental changes in one's home country, in the professional developments. It is a fact that for most companies, a work experience abroad may be a capital asset of qualification to get good qualified jobs.

- Besides, the Complutense University was a very prestigious one, and very well known. That added an extra value to my choice.

- Last, but not least, if one wants to further develop foreign language skills, immersion in another country is a way to get that. Not only the official language of the country, Spanish in this case, but also English, as in the working environment we usually use the latter.

Among the disadvantages or risks of studying abroad, we can mention the following. First, the expenses. Living in another country may not be cheap, and the funding received are small. The accommodation but also the often very expensive insurance in the host country, the price of air tickets, and in general, the standard of living of the foreign country, may make your financial situation difficult. In any case, it is usually possible to apply for several types of grants, depending on the destination, the program you join, the type of mobility, and the duration of the stay.

But in summary, I think that enjoying a mobility program between different universities is an opportunity to be seized. Moreover, the recently published figures on international students around the world show that this practice is growing because of the benefits you get.

\section{From the Host University}

Spain is full of assets that make it one of the most attractive countries in terms of education, living environment or culture. Choosing Spain is a guarantee of personal fulfillment in many respects, in one of the most welcoming countries in Europe.

In fact, this country has a world-renowned level of higher education, especially university. Some of the oldest universities in the world are located there. Not in vain it is one of the most requested destinations by international students [9].

In addition, the Spanish educational system is based on a network of public and private institutions that have made it rank 12th in terms of internal spending on research and development. The government helps and has policies to facilitate access to research. Studying in Spain is less expensive compared to other destinations and there are many scholarships available.

Spanish is the second mother tongue in the world by number of speakers, only behind Mandarin Chinese. It is the third language in the global score of speakers after English and Chinese. Today $7.6 \%$ of the world's population is Spanish-speaking. Studying in Spain is, therefore, a guarantee to improve your level of Spanish and access many job opportunities with this language. 


\subsection{The Destination University}

At an educational level, one of the goal of this Erasmus mobility is to initiate links between the two universities involved, so as to be ready to establish, afterwards, real long term collaboration between both institutions. In this case, they were the Polytech INP Clermont (Fig. 1) and Complutense University of Madrid (Fig. 3), that was the destination University chosen. The Complutense University offers top quality teaching and facilities.

The applicant had the chance to debate with the lectures at France the convenience of joining this university for a 4-month internship. Then he had to search for contacts within UCM. After a couple of emails, the candidate understood that the UCM, particularly the professor he contacted, was in line with his expectations. Even more, she was open to welcome foreign students despite the health context we are currently experiencing due to the COVID pandemic.

Particularly, the agreement was set with the Faculty of Physics, although in this case the supervisor of the exchange was at the Computer Sciences Faculty (Fig. 4). That is why the student was assigned an office at this Faculty, on the second floor, shared with other undergraduate and postgraduate students. That was also part of the benefits of this traineeship.

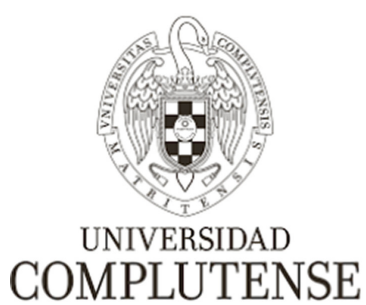

MADRID

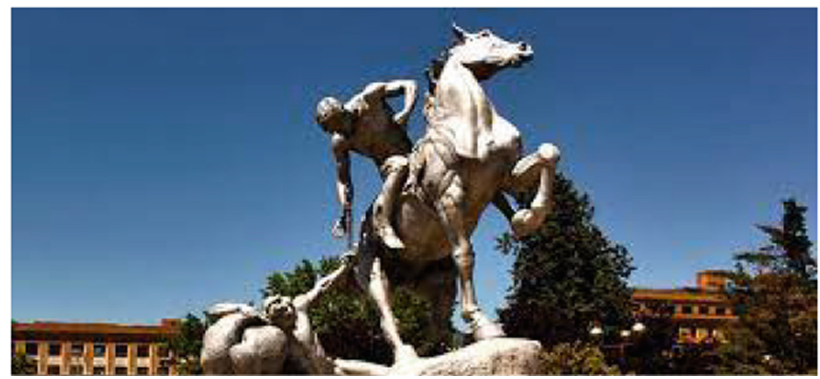

Fig. 3. University Complutense of Madrid, campus. Spain.
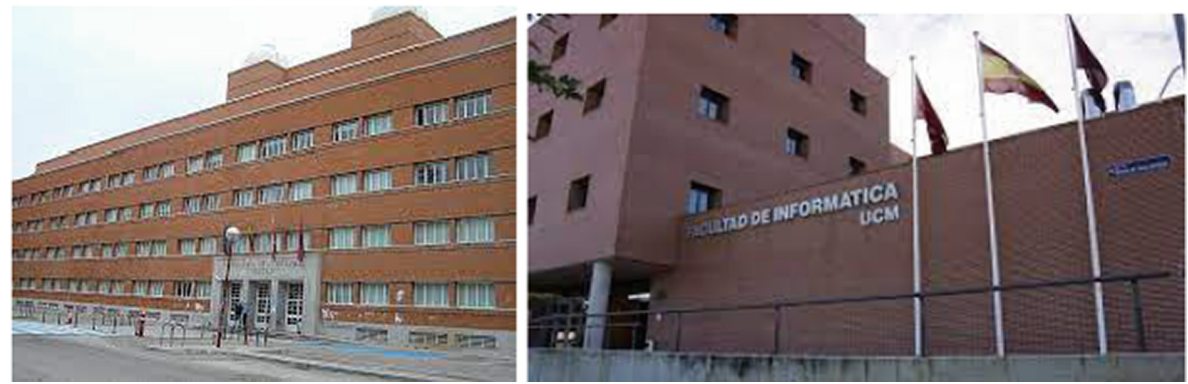

Fig. 4. Physics (left) and computer sciences (right) faculties.

The host institution was also interested because this way it will count on students with a suitable background to contribute to the research that was going on at different 
Departments and Faculties. Besides, the integration of foreign students contributes to the dynamism and internationalization of the Complutense University.

They checked my academic and professional background, as I had to send my CV. As the project I was going to be involved was about renewable energies, they considered my knowledge and experience sufficient. Indeed, I had already approached this field of energy, so to join it and try to contribute was something feasible. I would be able to understand the specific and technical terms and the main goals.

\section{Joining a Research Project on Renewable Energies}

As a student at Polytech Clermont Ferrand, I wanted to continue going deep into the field of energy, with which I have been somehow related through my studies and experience. To that end, I actively pursued an energy-related end-of-college internship.

During my last professional experiences, I had the perspective of developing skills in this area. In fact, I have worked in the rehabilitation of the Guy Thomas hospital in Riom (France). It had suffered a flood in one area, and I helped design a backup method of electricity distribution in the building, according to French standards. This work experience allowed me to achieve some experience in the energy grid. Indeed, I was able to understand how the facilities are connected to the electrical grid and to get hold of the technical vocabulary of this field. Therefore, the next step was to study other forms of energy, specifically renewable energies, which seemed to be very efficient and at the cutting edge.

This experience abroad could also be a great opportunity to collaborate in an international project in a new field for me, wind energy and, more specifically, floating wind turbines.

\subsection{The Project of the Traineeship}

In the area of renewable energies, wind energy is generating great expectations in terms of energy production, with high efficiency, but also causing a relatively important environmental impact. One solution proposed to alleviate the visual and noise impact of the on-land turbines is the installation of offshore wind turbines (OWT), and in particular, in the deep sea (floating offshore wind turbines, FOWT).

The floating turbines, which are quite recent and are now being developed all over the world, can be installed far from the coast, at great depths. But they need stable and flexible foundations. They present many interesting technological challenges [10].

Due to their situation on the sea surface, with strong winds, waves and currents, they are subject to intense loads and undesirable vibrations. Hence, the ability to reduce the impact of loads is extremely important as it allows for increased reliability and possibly the use of lighter and cheaper structures. But, on the other hand, the potential for wind energy is increased because the typical wind speed is above that of its land-based counterpart and the turbulence rate is lower.

In this research project, that was already going on, the control of floating wind turbines was addressed. All types of control that play a role in the performance of these renewable energy systems are studied, but the control of the blades to maintain the 
desired output power while reducing the vibrations is highlighted. The stability of the FOWT is a specific and important issue that the on-land ones do not present, and that even the bottom-fixed off-shore wind turbines (attached to the sea ground) do not have to such an extent.

The research includes the modelling of these complex, non-linear and unstable systems. These models are necessary in order to design the control strategies. And not only we are interested in the wind turbine model but in the environment, mainly waves and wind. It also deals with the control of the wind turbine, to optimize the energy that can be produced by applying intelligent techniques to the multivariable control of these devices [11].

Some of this goals have been already addressed, thought they are still open to research and to new finding. But to progress in the research, it was necessary to have simulation and real model where to test the control strategies proposed. Numerical tools have been applied to solve the complex dynamics of the floating devices but it was also quite necessary to have experimental installations where we can test the analytical and simulation developments $[12,13]$. So, we decided to design a prototype of a floating wind turbine, to test different control algorithms and to measure the vibrations.

\subsection{The Floating Wind Turbine Prototype}

A small-scale turbine would allow us to simulate the behaviors of full-scale systems (prototype) in such a way that the real values can be obtained from the values measured on a model by applying identified scaling factors. Thus, the project requires the design and implementation of a small scale replica of a floating turbine.

In order to make this prototype, it was first necessary to find out about the various platforms that currently exist for the floating turbines, and decide which one we were going to implement. After checking the four most common stabilization strategies, we decided to use barge-type floating wind turbines. The overturning torque is compensated by the high buoyancy of the system. The structure is fixed to the sea ground with mooring lines (Fig. 5, the one on the left).



Fig. 5. Four types of floating wind turbine. Barge-type on the left. 
Then we have to select the electronics component that were necessary to assemble the FOWT. First, the rotor with the blades. We have to research on internet and ask different providers because we need it to be angle to change the angle, in order to test the pitch control. After this searching, we bought the Dancing Wings Hobby kit, with two blades and a mechanical system that allows the system to set the angle. The rotor should be attached to a tube, to emulate the tower of the wind turbine.

An Arduino board was also bought to process the signals that are send to the servomotor that moves the blades. The Elegoo Arduino kit provides different sensors that were quite useful to measure different signals.

The Matlab software package is used to development a graphical interface to make easier for the user to control the inclination of the blades. The goal is to test different pitch control algorithms, so it was important to connect the PC with the control algorithms and the motor of the blades. The MPU-9250 connects the microcontroller via an I2C interface and has free libraries for the Arduino platform, allowing us to simply integrate it into any project.

A platform was built. It is just an horizontal surface where to fix the tower and the rotor. A system of four spring will be used to simulate the oscillations of the waves. In order to analyze the influence of the waves on the structure, an ultrasonic sensor was added. It allows us to measure the space between the platform and the seabed so, to measure the high of the waves.

This platform is equipped with an IMU sensor. This will allow us to measure the movement of the platform in real time from. Using Matlab software, we will analyze the platform's movements with the creation of three graphs: accelerometer, gyroscope, magnetometer. These will allow us to study in detail the influence of each parameter (pitch control, wind direction, wave movement).

\section{Conclusions}

This paper is focused on the experience of an Erasmus+ traineeship. It aims to show the benefits of enjoying this international experience, that in this particular type of programme, aims at getting the student collaborate in a research project.

Advantages of this mobility are shown, not only from the student point of view but also from the receiving university. The difficulties of the long administrative process that has to be carried out to get all the paperwork solved are also shared. As a conclusion, the involvement of both universities, host and origin, and the corresponding supervisors, is key to the success of these exchanges.

In addition, the importance is selecting a motivational project has been highlighted. In this case, besides being related to an attractive topic, such as wind energy, it is allowing the beneficiary to put into practice the knowledge he has acquired along his degree on different technological subjects (mechanical, electronics, computation, etc.). Working on a real problem opens a door to what research is and how to address it. Another conclusion that can be drawn is that it is important to find topics that motivate the students to get them involved, and to consider their background so they can address it successfully.

The result is quite positive. Although in this case the mobility is still going on, so far it has provided many benefits to both parts. 
As a suggestion for future experiences of this type, we would advise the applicants to pay attention to the selection criteria, and to the people in charge to deal with the students' questions without delay.

Acknowledgement. This work was partially supported by the Spanish Ministry of Science, Innovation and Universities under MCI/AEI/FEDER Project number RTI2018-094902-B-C21.

\section{References}

1. Ciesielkiewicz, M., Bonilla, C., Santos Peñas, M.: The Acquisition of Competences in Transnational Education Through the ePortfolio. In: Herrero, Á., Cambra, C., Urda, D., Sedano, J., Quintián, H., Corchado, E. (eds.) ICEUTE 2020. AISC, vol. 1266, pp. 75-83. Springer, Cham (2021). https://doi.org/10.1007/978-3-030-57799-5_8

2. Zagirnyak, M., Gladyr, A., Nozhenko, V.: Results and problems of international academic exchanges. In: 2020 IEEE Problems of Automated Electrodrive. Theory and Practice (PAEP), pp. 1-4. IEEE (2020)

3. Gabriels, W., Benke-Åberg, R.: Student exchanges in times of crisis. Erasmus Student Network Aisbl, Europe. https://tinyurl.com/5n773k2 (2020)

4. Koris, R., Mato-Díaz, F., Hernández-Nanclares, Núria.: From real to virtual mobility: Erasmus students' transition to online learning amid the COVID-19 crisis. Eur. Educ. Res. J. 20(4), 463-478 (2021). https://doi.org/10.1177/14749041211021247

5. Huisman, J., Vlegels, J., Daenekindt, S., Seeber, M., Laufer, M.: How satisfied are international students? The role of town, gown and motivations. Compare: J. Comp. Int. Educ., 1-19 (2021)

6. Teichler, U.: Student mobility in the framework of ERASMUS: findings of an evaluation study. Eur. J. Educ. 31(2), 153-179 (1996)

7. Erasmus+ Programme: https://ec.europa.eu/programmes/erasmus-plus/about_en

8. Soares, M.E., Mosquera, P.: Linking development of skills and perceptions of employability: the case of Erasmus students. Econ. Res.-Ekonomska Istraživanja 33(1), 2769-2786 (2020)

9. Breznik, K., Skrbinjek, V.: Erasmus student mobility flows. Eur. J. Educ. 55(1), 105-117 (2020)

10. Tomás-Rodríguez, M., Santos, M.: Modelling and control of floating offshore wind turbines. Rev. Iberoamericana Autom. Inform. Ind. 16(4), 381-390 (2019)

11. Sierra-García, J.E., Santos, M.: Performance analysis of a wind turbine pitch neurocontroller with unsupervised learning. Complexity 2020, 1-15 (2020). https://doi.org/10.1155/2020/ 4681767

12. Sánchez, C., Muñoz de la Peña, D., Gómez-Estern, F.: Automated generation of control design benchmark problems for computer-assessed education with Doctus. Rev. Iberoamericana Autom. Inform. Ind. 17(1), 1-9 (2020). https://doi.org/10.4995/riai.2019.11243

13. Lerma, E., Costa-Castelló, R., Griñó, R., Sanchis, C.: Tools for teaching digital control in engineering degrees. Rev. Iberoamericana Autom. Inform. Ind. 18(2), 189-199 (2021) 


\section{Author Queries}

Chapter 34

\begin{tabular}{|c|l|c|}
\hline Query Refs. & Details Required & Author's response \\
\hline AQ1 & $\begin{array}{l}\text { This is to inform you that corresponding author has been identified } \\
\text { as per the information available in the Copyright form. }\end{array}$ & \\
\hline
\end{tabular}




\section{Please correct and return this set}

Please use the proof correction marks shown below for all alterations and corrections. If you wish to return your proof by fax you should ensure that all amendments are written clearly in dark ink and are made well within the page margins.

\begin{tabular}{|c|c|c|}
\hline Instruction to printer & Textual mark & Marginal mark \\
\hline Leave unchanged & ... under matter to remain & ( $)$ \\
\hline $\begin{array}{l}\text { Insert in text the matter } \\
\text { indicated in the margin }\end{array}$ & $\Lambda$ & $\begin{array}{l}\text { New matter followed by } \\
h \text { or } h \otimes\end{array}$ \\
\hline Delete & $\begin{array}{l}\text { I through single character, rule or underline } \\
\text { or }\end{array}$ & $\sigma$ or $\sigma / 2$ \\
\hline $\begin{array}{l}\text { Substitute character or } \\
\text { substitute part of one or } \\
\text { more word(s) }\end{array}$ & I through letter or & $\begin{array}{l}\text { new character / or } \\
\text { new characters / }\end{array}$ \\
\hline Change to italics & — under matter to be changed & $\leftarrow$ \\
\hline Change to capitals & $\equiv$ under matter to be changed & $\equiv$ \\
\hline Change to small capitals & $=$ under matter to be changed & $=$ \\
\hline Change to bold type & $\sim$ under matter to be changed & $\sim$ \\
\hline Change to bold italic & $\bar{\sim}$ under matter to be changed & 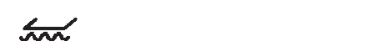 \\
\hline Change to lower case & Encircle matter to be changed & $\Rightarrow$ \\
\hline Change italic to upright type & (As above) & \\
\hline Change bold to non-bold type & (As above) & nor \\
\hline Insert 'superior' character & $\begin{array}{l}/ \text { through character or } \\
\alpha \text { where required }\end{array}$ & $\begin{array}{l}y^{\prime} \text { or } y \\
\text { under character } \\
\text { e.g. } y^{2} \text { or } y^{2}\end{array}$ \\
\hline Insert 'inferior' character & (As above) & $\begin{array}{l}\lambda \\
\text { over character } \\
\text { e.g. } \hat{\Sigma}\end{array}$ \\
\hline Insert full stop & (As above) & $\odot$ \\
\hline Insert comma & (As above) & , \\
\hline Insert single quotation marks & (As above) & $\begin{array}{l}\dot{y} \text { or } \dot{x} \text { and/or } \\
\dot{y} \text { or } \dot{y}\end{array}$ \\
\hline Insert double quotation marks & (As above) & $\begin{array}{l}\ddot{y} \text { or } \ddot{x} \text { and/or } \\
\ddot{y} \text { or } \ddot{x}\end{array}$ \\
\hline Insert hyphen & (As above) & 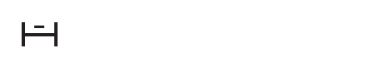 \\
\hline Start new paragraph & 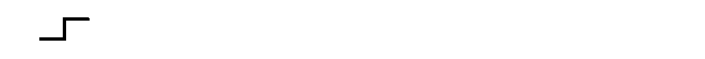 & 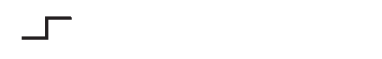 \\
\hline No new paragraph & 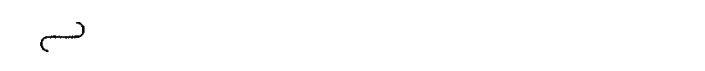 & 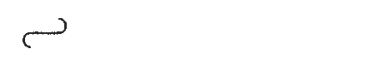 \\
\hline Transpose & $\sqcup$ & $\sqcup$ \\
\hline Close up & linking $\bigcirc$ characters & \\
\hline $\begin{array}{l}\text { Insert or substitute space } \\
\text { between characters or words }\end{array}$ & $\begin{array}{l}\text { I through character or } \\
\Lambda \text { where required }\end{array}$ & \\
\hline $\begin{array}{l}\text { Reduce space between } \\
\text { characters or words }\end{array}$ & $\begin{array}{l}\text { between characters or } \\
\text { words affected }\end{array}$ & $\uparrow$ \\
\hline
\end{tabular}

